\title{
Reproductive cycle of the mangrove oyster, Crassostrea rhizophorae (Bivalvia: Ostreidae) cultured in a macrotidal high-salinity zone on the Amazon mangrove coast of Brazil
}

\author{
Ícaro ANTONIO ${ }^{1,2 *}$, Ana SOUSA ${ }^{2}$, Tiago LENZ ${ }^{3}$, Izabel FUNO ${ }^{4}$, Rodolf LOPES ${ }^{5}$, Marina FIGUEIREDO ${ }^{1,2}$ \\ 1 Universidade Estadual do Maranhão, Centro de Ciências Agrárias, CEP 65055-310, São Luís, MA, Brazil \\ ${ }^{2}$ Universidade Estadual do Maranhão, Programa de Pós-graduação em Recursos Aquáticos e Pesca, CEP 65055-310, São Luís, MA, Brazil \\ ${ }^{3}$ Instituto Federal de Educação, Ciência e Tecnologia de Alagoas, CEP 57200-000, Penedo, AL, Brazil \\ ${ }^{4}$ Instituto Federal de Educação, Ciência e Tecnologia do Maranhão, CEP 65095-460, São Luís, MA, Brazil \\ 5Universidade Federal Rural de Pernambuco, Programa de Pós-graduação em Recursos pesqueiros e Aquicultura, CEP 52171-900, Recife, PE, Brazil \\ * Corresponding author: icaro_gomes@hotmail.com; (10) https://orcid.org/0000-0002-4538-3522
}

\begin{abstract}
This study aimed to establish the reproductive cycle of the mangrove oyster, Crassostrea rhizophorae cultured in the macrotidal estuary of the Paciência River, Maranhão state, on the northeastern coast of Brazil, and its relationship with environmental factors. Oysters were collected monthly throughout 2013 for histological analysis of sex ratio, gonadal development and condition index. The sex ratio was 1:1.39 (M:F) and only 5 specimens presented hermaphroditism. The breeding process was continuous throughout the year and mature (IIIA stage) and spawning oysters (IIIB stage) were present in practically all months. Low variation in temperature seemed to be the main factor for the continuity of the reproductive cycle. Besides temperature, the relationship between rainfall, salinity and primary productivity affected the stimulus and timing of reproductive events. The rainy season, with low values of salinity and high values of chlorophyll $a$ and particulate organic matter, appeared to be the main reproductive period, with release of gametes and production and maturation of new gamete cohorts in the short term. In the tropics, where gamete maturation and release seem to be continuous and concomitant, the condition index does not appear to be the best method to assess reserve accumulation peaks and gonadal repletion.
\end{abstract}

KEYWORDS: reproduction; spawning; environmental factors; brackishwater aquaculture

\section{Ciclo reprodutivo da ostra do mangue, Crassostrea rhizophorae (Bivalvia: Ostreidae) cultivada em uma zona de macromarés de alta salinidade na costa de manguezais da Amazônia do Brasil}

\section{RESUMO}

Este estudo teve como objetivo estabelecer o ciclo reprodutivo da ostra do mangue, Crassostrea rhizophorae cultivada no estuário de macromarés do Rio Paciência, Maranháo, na costa nordeste do Brasil, e suas relaçóes com fatores ambientais. As ostras foram coletadas mensalmente ao longo de 2013 para análise histológica da proporção sexual, desenvolvimento gonadal e índice de condição. A proporção sexual foi de 1:1,39 (M:F) e apenas 5 espécimes apresentaram hermafroditismo. A maturação foi contínua ao longo do ano e ostras maduras (estágio IIIA) e em desova (estágio IIIB) estiveram presentes em praticamente todos os meses. A baixa variação de temperatura parece ser o principal fator para a continuidade da gametogênese. Entretanto, além da temperatura, a relação entre precipitação, salinidade e produtividade primária afetou o estímulo e o tempo dos eventos reprodutivos. A estação chuvosa, com baixos valores de salinidade e altos valores de clorofila a e matéria orgânica particulada, pareceu ser o principal período reprodutivo, com liberação de gametas e produção e maturação de novas coortes de gametas em curto prazo. Nos trópicos, onde a maturação e liberação de gametas parecem ser contínuas e concomitantes, o índice de condição não se apresenta como o melhor método para avaliar os picos de acúmulo de reserva e desenvolvimento gonadal.

PALAVRAS-CHAVE: reprodução; desova; fatores ambientais; aquicultura em água salobra 


\section{INTRODUCTION}

The mangrove oyster, Crassostrea rhizophorae (Guilding 1828 ) is found mainly in mangroves, bays, and estuarine regions, fixed on rocks and consolidated substrates (Rios 2009). In mangroves, it is usually found settled on the red mangrove, Rhizophora mangle (Linnaeus 1753) roots in the intertidal region (Bacon 1971). The oysters of the Crassostrea genus are oviparous and dioecious and may present sequential hermaphroditism without sexual dimorphism with external fertilization followed by larval planktotrophic development. The gamete release in tropical regions occurs continuously during the year, with evidence of spawning peaks stimulated by environmental variables (Vélez 1977; Lenz and Boehs 2011; Paixão et al. 2013).

The Island of Maranháo, located on the northeastern Brazilian coast, is part of the largest and best-preserved continuous mangrove area in Brazil, known as the Amazon Macrotidal Mangrove Coast (AMMC) (Nascimento Jr et al. 2013; Schettini et al. 2020). The AMMC is $480 \mathrm{~km}$ long with $7600 \mathrm{~km}^{2}$ of continuous mangrove forests along the coasts of the states of Pará and Maranhão (Souza Filho 2005). The coastal environments of this region are influenced by the macrotide phenomenon, reaching tidal amplitudes of up to $7 \mathrm{~m}$. This phenomenon, associated with the low slope of the local coastal plains, and two well-defined annual seasons, a rainy season (February to July) and a dry season (August to January), results in a yearly variation in coastal salinity from 0.1 to 49.2 (Sampaio et al. 2020).

Among the environmental variables with a wide range of variation in Amazon coastal waters, salinity and primary productivity are the most important in the modulation of oyster reproductive biology (Pantoja et al. 2020). Salinity appears to exert a strong influence on the maturation and spawning of oysters in the Amazon (Paixáo et al. 2013). Studies indicate that the mangrove oyster, Crassostrea rhizophorae tolerates salinities from 5 to 35 (Guimarães et al. 2008), but, in our study area, salinity exceeds 40 during the dry period (Funo et al. 2019). In addition, primary productivity increases during the Amazon rainy season, suggesting that rainfall influences the composition, density, biomass, and diversity of phytoplankton (Costa et al. 2011). The interaction among composition and abundance of phytoplankton, salinity, and local hydrodynamics modulates metabolic activity of the reproduction of bivalves, through the supply of essential fatty acids (Silva et al. 2020).

In this context, the present study sought to determine the periods of more significant reproductive activity, and the influence of environmental variables on maturation and spawning of C. rhizophorae cultured in the Paciência River estuary on Maranhão Island, at the eastern extreme of the AMMC. This information has not previously been available for C. rhizophorae in the AMMC and can help to determine the best periods for oyster recruitment, thus supporting oyster farming and management actions that seek the sustainable exploitation of natural oyster beds.

\section{MATERIAL AND METHODS}

\section{Study area and environmental characteristics}

The oysters used in this study were collected in a culture area located in the Paciência River estuary, Maranhão state,

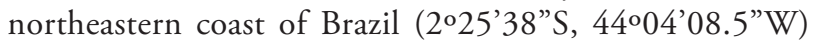
(Figure 1). The culture was carried out on a raft, and oysters were kept inside cages, with five circular trays, at an average density of 50 oysters tray ${ }^{-1}$. Oyster spats used in the culture were recruited using artificial PET bottle collectors installed in the Paciência estuary. Oyster spats were genetically

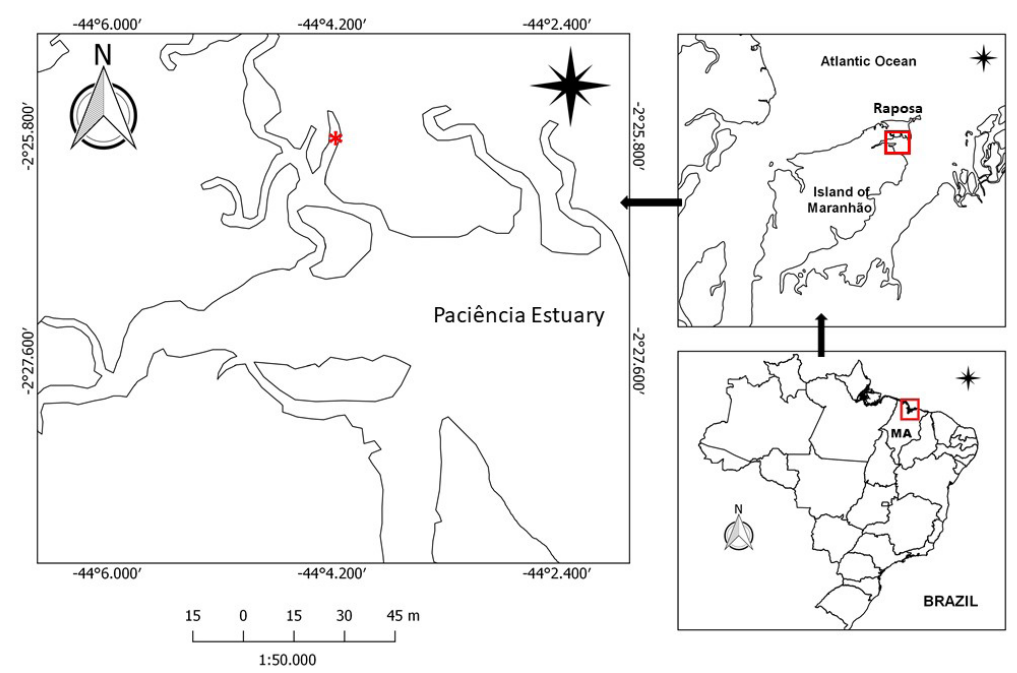

Figure 1. Location of the culture area of mangrove oysters, Crassostrea rhizophorae in the Paciência River estuary, municipality of Raposa, Maranhão state, Brazil. The asterisk marks the raft location in the estuary. This figure is color in the electronic version. 
characterized by the PCR-Multiplex species-specific technique and confirmed as $C$. rhizophorae by the presence of $640 \mathrm{bp}$ (Lopes et al. 2018).

Environmental variables were measured fortnightly at low tide by the raft where oysters were collected. Data on temperature $\left({ }^{\circ} \mathrm{C}\right)$, salinity $(\mathrm{psu}), \mathrm{pH}$ and dissolved oxygen $\left(\mathrm{mg} \mathrm{L}^{-1}\right)$ were obtained with a multiparameter YSI 556MPS; and transparency $(\mathrm{cm})$ with a Secchi disk. Chlorophyll $a$ and suspended particulate matter data (organic and inorganic fractions) $\left(\mathrm{mg} \mathrm{L}^{-1}\right)$ were obtained by filtering two liters of water and analyzed following the protocol of Jeffrey and Humphrey (1975) for chlorophyll $a$ and Cubillo et al. (2012) for total particulate matter (TPM), particulate organic matter (POM) and particulate inorganic matter (PIM). The rainfall data were obtained from the Geoenvironmental Nucleus - NUGEO of Universidade Estadual do Maranhão.

\section{Oyster sampling and biometric measurements}

Every month from January to December 2013, 30 Crassostrea rhizophorae oysters were randomly collected from the culture cages (total $n=360$ ). Twenty individuals were assigned for histological analysis and ten for condition index determination. Once collected, oysters were immediately transported to the Laboratory of Physioecology, Reproduction and Cultivation of Marine Organisms of Universidade Estadual do Maranhão for analysis. Each oyster was measured for shell height (anteroposterior axis) with a $0.1-\mathrm{mm}$ precision caliper, and weighed (for total weight, fresh shell weight and fresh soft tissue weight) using a 0.001 -g precision balance. Tissue was left on absorbent paper for 5 min to remove excess water before weighing to determine the fresh soft tissue weight.

\section{Condition index}

The condition index (CI) was calculated monthly based on the dry weight of 10 oysters. The soft parts and shells of the oysters were placed in preweighed aluminum cups and dried at $60^{\circ} \mathrm{C}$ to constant dry weight. The condition index was calculated as $\mathrm{CI}=\mathrm{W} 1 \times 1000 / \mathrm{W} 2$, where W1 is the dry soft-part weight of 10 oysters and W2 is the dry-shell weight of the same 10 oysters.

\section{Histological analysis}

Gonadal development stages were evaluated monthly through histological analysis of approximately 17 oysters (total $n=196$ ). The meat section between the labial palps and pericardial cavity was fixed in Davidson saline solution for 24 $\mathrm{h}$ and preserved in $70 \%$ ethanol for subsequent dehydration by successive baths in different ethanol gradations and then incorporated into paraffin. Thin cross-sections of $5 \mu \mathrm{m}$ were obtained with a semiautomatic microtome. The slides were stained with Harris Hematoxylin and Eosin (CastilhoWestphal et al. 2015) and mounted on glass slides in mounting medium (Entellan).
The slides were examined under light microscopy and microphotographs were taken of selected material. Males, females and hermaphrodites were differentiated by the presence of cells of spermatogenesis or oogenesis. The gonadal development stages were determined using the scale described by Antonio and Camacho (2019), as follows: stage 0 - sexual rest; I - gonial multiplication; II - gametogenesis; IIIA - maturation; IIIB - total or partial emptying; IIIC recovery between successive releases and; IIID - end of the breeding season (spent). The spawning season was evaluated by determining the monthly distribution of the frequency of different maturation stages concerning the condition index.

\section{Statistical analysis}

Differences in environmental variables between the rainy and dry seasons were evaluated with Student's $t$ tests. The 12 monthly samples of size (shell height) and CI were compared with one-way ANOVAs after confirming the normal distribution of the data with Kolmogorov-Smirnov tests and homogeneity of variance with Cochran tests, and then compared pairwise with post hoc Student-NewmanKeuls (SNK) tests.

The sex ratio of male to female oysters was determined monthly and for the overall and tested for significant differences with Chi-square non-parametric tests. Statistical analyses were performed using Statistica 7 and a significance level of $\alpha=5 \%$.

\section{RESULTS}

During the monitoring period, the salinity varied from 31 in April to 42 in December, with significantly higher values in the dry season (Table 1; Figure 2a). During the dry season, the dissolved oxygen and water transparency were significantly higher (Table 1; Supplementary Material, Figure S1). Monthly rainfall, which varied from 0.4 to $296 \mathrm{~mm}^{3}$, chlorophyll $a$ and particulate organic matter were significantly higher in the rainy season (Table 1; Figure 2). There was no significant difference between seasons for temperature and $\mathrm{pH}$ (Table 1; Supplementary Material, Figure S2).

The condition index varied significantly $\left(\mathrm{F}_{(11,108)}=7.21, P\right.$ $<0.0001$ ) among months (Figure 3 ). During the rainy season, the CI increased continuously and peaked in May (53.5 \pm 16.5). The CI then decreased significantly between May and July, increased again in August, followed by a continuous decrease until November, when the lowest value was observed $(20.0 \pm 12.5)$ (Figure 3).

Mean shell height varied from $59.5 \pm 6.6 \mathrm{~mm}$ in January to $68.9 \pm 9.1 \mathrm{~mm}$ in March $(\mathrm{n}=360)$, with no significant difference among months $\left(\mathrm{F}_{(11,347)}=4.29, P=0.0523\right)$. No sexual dimorphism was observed macroscopically. The microscopic analyses identified $40.8 \%$ of males $(n=80)$, $56.6 \%$ of females $(n=111)$ and hermaphroditism was 

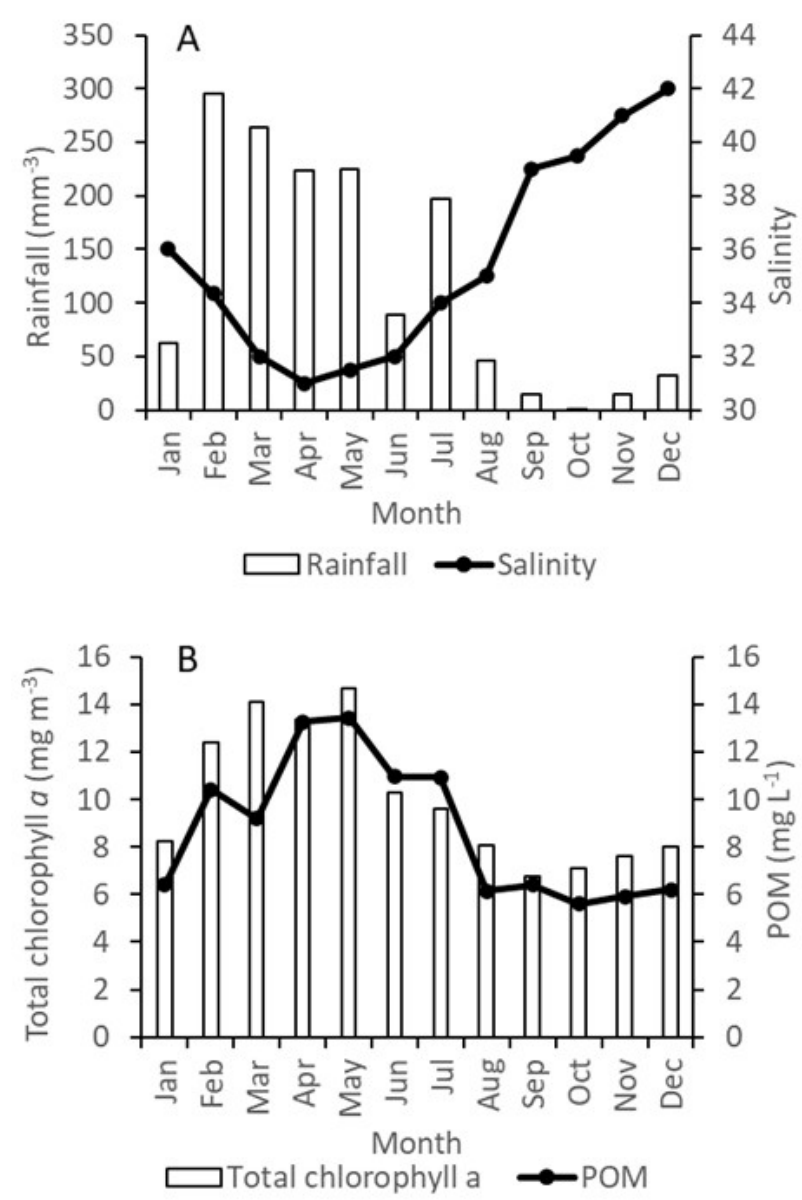

Figure 2. Mean monthly values of rainfall and salinity (A), and total chlorophyll $a$ and particulate organic matter (POM) (B), at the culture area of mangrove oysters, Crassostrea rhizophorae in the estuary of the Paciência River, Maranhão, Brazil in 2013.

Table 1. Values of environmental variables during the rainy (February-July) and dry (August - January) seasons of 2013 at the culture area of mangrove oysters, Crassostrea rhizophorae in the estuary of the Paciência River, Maranhão, on the Amazon Macrotidal Mangrove Coast in Brazil. TPM = total particulate matter; $\mathrm{POM}=$ particulate organic matter; PIM = particulate inorganic matter. Values are the mean \pm stadard deviation.

\begin{tabular}{lcccc}
\hline $\begin{array}{l}\text { Environmental } \\
\text { variables }\end{array}$ & $\begin{array}{c}\text { Rainy } \\
\text { season }\end{array}$ & Dry season & $\begin{array}{c}\boldsymbol{t} \\
\text { value }\end{array}$ & $\begin{array}{c}\boldsymbol{P} \\
\text { value }\end{array}$ \\
\hline Temperature $\left({ }^{\circ} \mathrm{C}\right)$ & $28.58 \pm 0.86$ & $29.74 \pm 0.44$ & -2.94 & 0.054 \\
pH & $7.52 \pm 0.15$ & $7.37 \pm 0.47$ & 0.75 & 0.473 \\
Dissolved oxygen $\left(\mathrm{mg} \mathrm{L}^{-1}\right)$ & $4.20 \pm 0.58$ & $5.08 \pm 0.63$ & -2.49 & $\mathbf{0 . 0 3 2}$ \\
\hline Salinity $(\mathrm{psu})$ & $32.48 \pm 1.37$ & $38.75 \pm 2.75$ & -5.00 & $<\mathbf{0 . 0 0 1}$ \\
Rainfall $\left(\mathrm{mm}^{3}\right)$ & $216.13 \pm 71.12$ & $28.10 \pm 22.67$ & 6.17 & $<\mathbf{0 . 0 0 1}$ \\
\hline Water transparency $\left(\mathrm{cm}^{2}\right)$ & $42.18 \pm 6.82$ & $70.39 \pm 5.57$ & -7.84 & $<\mathbf{0 . 0 0 1}$ \\
\hline Total chlorophyll a $\left(\mathrm{mg} \mathrm{m}^{-3}\right)$ & $12.42 \pm 2.07$ & $7.63 \pm 0.60$ & 5.44 & $<\mathbf{0 . 0 0 1}$ \\
\hline TPM $\left(\mathrm{mg} \mathrm{L}^{-1}\right)$ & $57.04 \pm 3.80$ & $35.71 \pm 5.84$ & 7.38 & $<\mathbf{0 . 0 0 1}$ \\
POM (mg L-1) & $11.38 \pm 1.67$ & $6.11 \pm 0.31$ & 7.60 & $<\mathbf{0 . 0 0 1}$ \\
\hline PIM (mg L-1) & $45.66 \pm 3.41$ & $29.93 \pm 5.75$ & 5.76 & $<\mathbf{0 . 0 0 1}$ \\
\hline
\end{tabular}

$P$ values in bold indicate significant seasonal difference (Student's $s$ test, degrees of freedom $=10$ ).

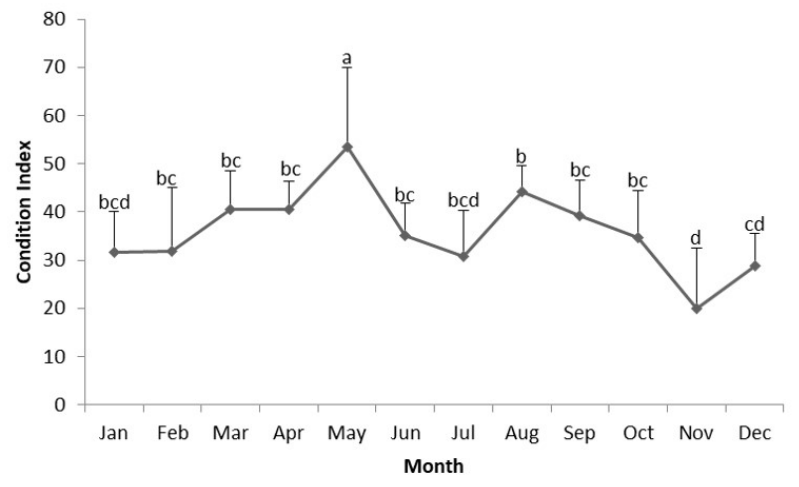

Figure 3. Monthly variation of the condition index (mean + SD) of mangrove oysters, Crassostrea rhizophorae cultured in 2013 in the estuary of the Paciência River, Maranhão, Brazil (monthly $n=10$ ). Dots represent the mean and bars the standard deviation. Different letters represent significant pairwise differences by the SNK post hoc test.

observed in $2.6 \%$ of the oysters $(n=5)$. The overall sex ratio was 1:1.39 (M:F), but the difference was not significant $\left(\chi^{2}=\right.$ $13.28, \mathrm{df}=23, P=0.945)$. The monthly sex ratio significantly favored females in June $\left(\chi^{2}=5.4, \mathrm{df}=1, P=0.020\right)$ and July $\left(\chi^{2}=4.76, \mathrm{df}=1, P=0.029\right)$.

We detected no male in sexual rest (stage 0 ), nor in stage I (spermatogonia multiplication). Spermatogenesis development (stage II) occurred during the dry season (Figure 4; Table 2), with the prevalence of spermatids filling the acinus and the appearance of the first spermatozoids (Figure 5a). Mature males (IIIA stage) were observed in almost all months of the year, with prevalence during the dry season (34.1\%) (Table 2). At this stage, the gonads contained germ cells and spermatogonium anchored to the tubule walls, and spermatids and spermatozoids filling the lumen (Figure 5b).

Partial or total spawning (IIIB) was observed throughout the year, with higher values in March (66.7\%), June (66.7\%) and October (87.5\%) (Figure 4). Spermatozoid release is

Table 2. Relative frequency (\%) of gonadal development stages in males and females of mangrove oysters, Crassostrea rhizophorae cultured in the estuary of the Paciência River, Maranhão, on the Amazon Macrotidal Mangrove Coast in Brazil, during the rainy and dry seasons in 2013.

\begin{tabular}{lcc}
\hline Stage & Rainy season & Dry season \\
\hline Males & $(\mathrm{n}=35)$ & $(\mathrm{n}=45)$ \\
II (Gametogenesis) & 0 & 6.8 \\
IIIA (Maturing) & 20.0 & 34.1 \\
IIIB (Spawning) & 45.7 & 50.0 \\
IIIC (Recovery) & 34.3 & 9.1 \\
IIID (Breeding end) & 0 & 0 \\
\hline Females & $(\mathrm{n}=61)$ & $(\mathrm{n}=50)$ \\
II (Gametogenesis) & 5.0 & 4.2 \\
IIIA (Maturing) & 18.3 & 31.3 \\
IIIB (Spawning) & 31.7 & 47.9 \\
IIIC (Recovery) & 38.3 & 8.3 \\
IIID (Breeding end) & 6.7 & 8.3 \\
\hline
\end{tabular}




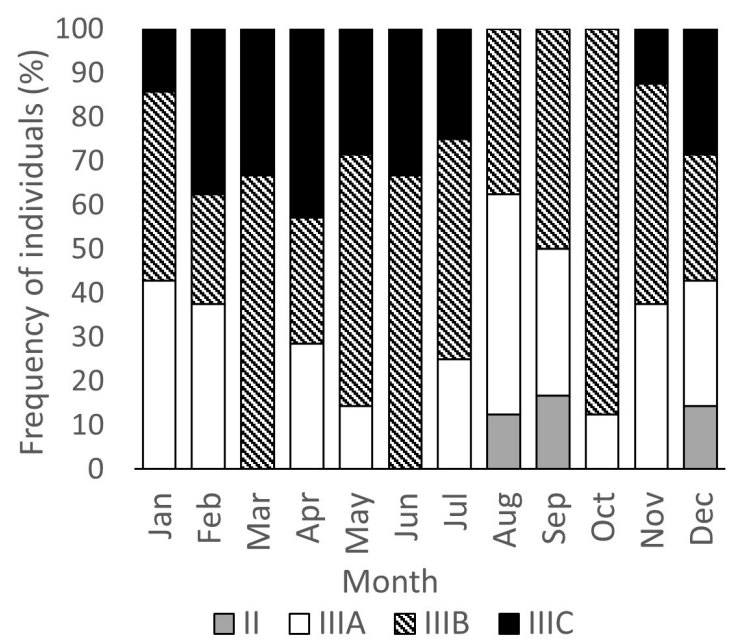

Figure 4. Variation in monthly relative frequencies (\%) of gonadal development stages in males of mangrove oysters, Crassostrea rhizophorae cultured in 2013 in the estuary of the Paciência River, Maranhão, Brazil (monthly $n=7$ ).

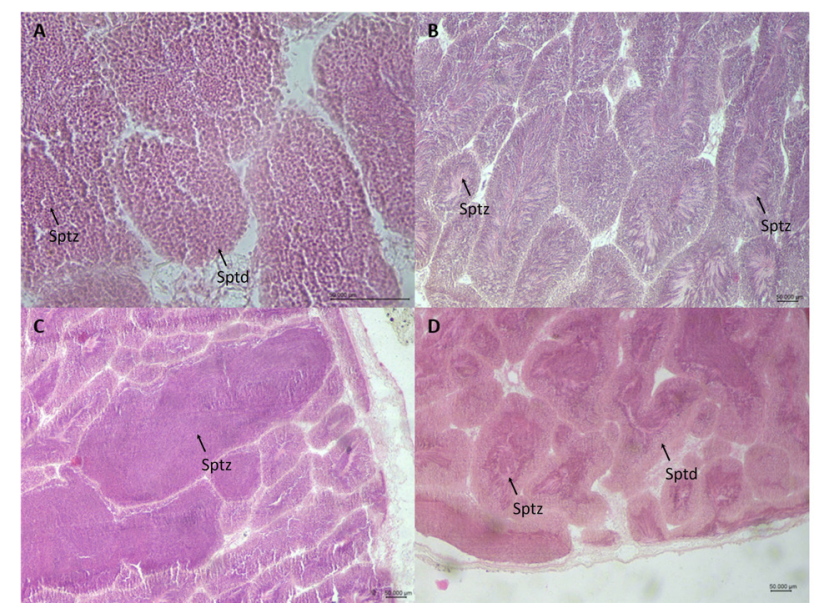

Figure 5. Male gonadal development stages of Crassostrea rhizophorae cultured in 2013 in the estuary of the Paciência River, Maranhão, Brazil. A - Stage II (gametogenesis); B - Stage IIIA (maturation); C - Stage IIIB (spawning); D - Stage IIIC (recovery). Scale bars $=50 \mu \mathrm{m}$. Sptd $=$ spermatids; $S p t z=$ spermatozoids. This figure is color in the electronic version.

characterized by the disorganization of the swirling form of the spermatozoa, leaving empty spaces and increasing the amount of connective tissue among the tubules (Figure 5c). The recovery period (IIIC) was more evident in the rainy season (Table 2), which shows that males continuously released spermatozoids and matured new cohorts during this season (Figure 4; Figure 5d). Spent males (IIID stage) were not observed during the study period.

We observed no females in stage 0 (rest) and stage I (oogonia multiplication). Females in stage II (oogenesis) were observed in a few months of the year, mainly in the rainy-dry transition (Figure 6). This stage was characterized by intense folliculogenesis and oogenesis, with oocytes in vitellogenesis

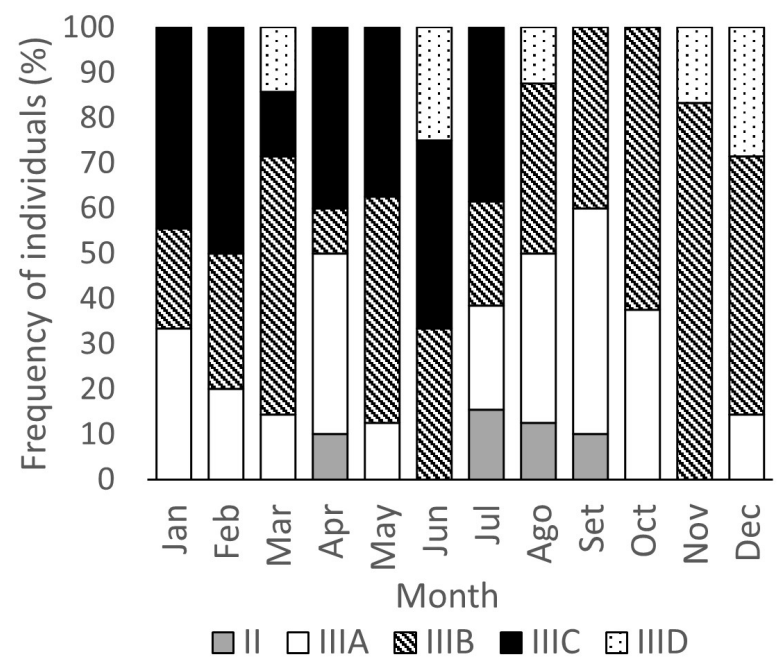

Figure 6. Variation in monthly relative frequencies (\%) of gonadal development stages in females of mangrove oysters, Crassostrea rhizophorae cultured in 2013 in the estuary of the Paciência River, Maranhão, Brazil (monthly $n=10$ ).

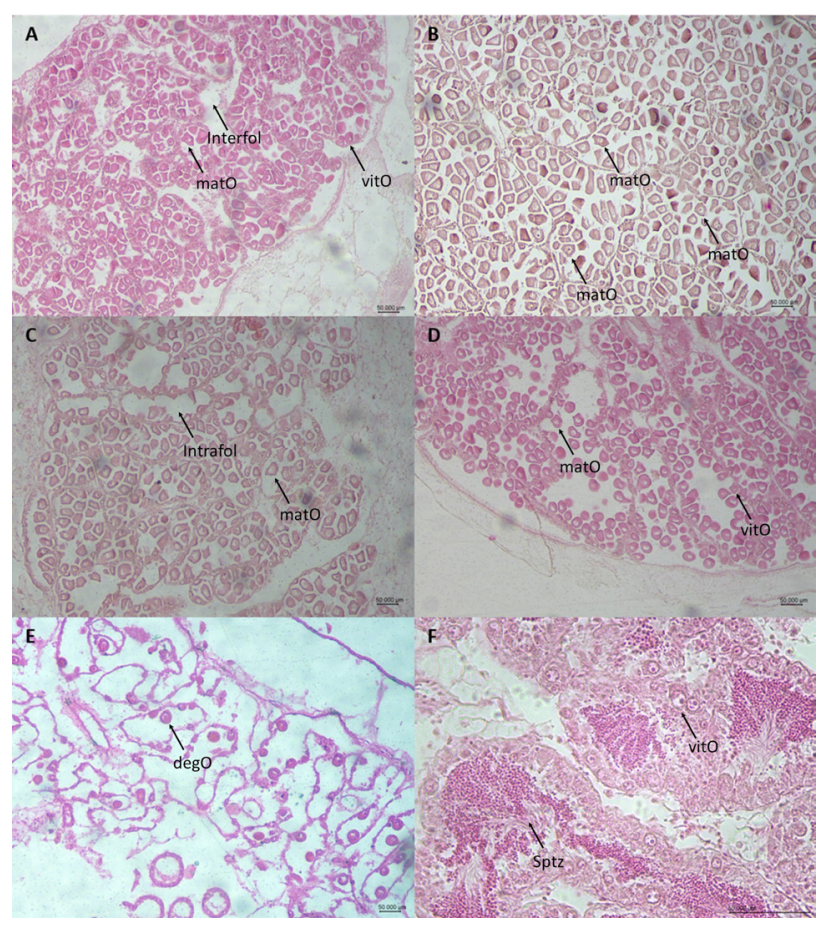

Figure 7. Female gonadal development stages of mangrove oysters, Crassostrea rhizophorae cultured in 2013 in the estuary of the Paciência River, Maranhão, Brazil. A - Stage II (gametogenesis); B - Stage IIIA (maturation); C - Stage IIIB (spawning); D - Stage IIIC (recovery); E - Stage IIID (end of breeding season); F - Protogynous hermaphrodite. Scale bars $=50 \mu \mathrm{m}$. matO = mature oocyte; vitO = vitellogenic oocyte; Interfol = interfollicular connective tissue; Intrafol = intrafollicular space; degO = degenerating oocyte; Sptz = spermatozoids. This figure is color in the electronic version. 
and the first mature oocyte appearance (Figure 7a). Mature females (IIIA stage) were more evident in the dry season (Table 2), with values that reached 50\% in September (Figure 6). At this stage, mature oocytes were juxtaposed and free in the follicle lumen, filling almost its entirety. The follicles had thin walls and less connective tissue filling the gonads. At the end of this phase, mature oocytes were ready to be released to the external environment (Figure 7b).

Spawning females (IIIB) were observed in all months (Figure 6), with high frequencies in the dry season (Table 2), especially in November (83.3\%) (Figure 6). Once the maturation of oocytes was reached, the first releases occurred, which filled the gonoducts, showing intrafollicular spaces. At the advanced or total emptying stage, mature oocytes appeared scattered in the lumen, with a gradual increase in empty spaces in the follicle proportional to the progression of the spawning process (Figure $7 \mathrm{c}$ ).

Females in the recovery stage between successive spawning events were more frequent in the rainy season (Table 2). At this stage, the follicles size decreased, resulting in a compressed appearance, a predominance of interfollicular connective tissue and a thickening of the walls. The number of germ cells increased while mature oocytes decreased (Figure 7d).

Spent females (stage IIID), represented by individuals that achieved the full release of their gametes, were observed in low proportion in March (14.3\%), August (12.5\%) and November (16.7\%), reaching higher values in December $(28.6 \%)$ and June (25\%) (Figure 6). After the last spawning, the follicles were small and practically empty, leaving only a few mature oocytes with signs of cytolysis. The follicles were invaded internally and externally by hemocytes, with a probable degenerative function related to remaining gamete cells, and a large area of the mantle was composed of connective tissue (Figure 7e). In hermaphrodites, female gametes outnumbered male gametes (Figura 7f).

\section{DISCUSSION}

The timing of gamete release in bivalve mollusks appears to differ at different latitudes (Gomes et al. 2014). In tropical regions, gamete release is continuous, whereas, in temperate areas, spawning occurs only in the warmest months of the year, mainly due to the broader temperature range and variation in the photoperiod (Rodríguez-Jaramillo et al. 2008). The low temperature variation in the tropics, associated with favorable physical conditions, seems to be mainly responsible for a continuous reproductive cycle (Bacon 1971).

Reproductive activity in male and female Crassostrea rhizophorae in the Paciência estuary was continuous yearround, and stages of maturation (IIIA stage) and spawning (IIIB stage) were present in practically all months. The stages of sexual rest (stage 0) and germ cell multiplication (stage I) were not observed in any of the analyzed oysters, which agrees with Nascimento and Lunetta (1978), who observed that these stages are extremely rare in populations of native oysters in northeastern Brazil. These results reinforce the hypothesis that $C$. rhizophorae has accelerated maturation and continuous reproduction during the year in low latitudes (Lenz and Boehs 2011).

Besides temperature, the relationship between rainfall and salinity seems to affect the stimulus and timing of reproductive events. Rainfall monitoring and its interaction with salinity during the rainy and dry seasons can provide crucial information on the abiotic factors that influence the oyster reproductive process (Paixão et al. 2013). In the study area, macrotides result in annual variation in salinity. In the rainy season, salinity tends to decrease during low tide and equates to coastal salinity during high tide. However, in the dry season, the salinity tends to increase during low tide due to the evaporation caused by solar irradiation and surpasses coastal salinity during high tide. Similarly, in arid coastal regions of Australia, increased evaporation and low rainfall cause estuarine salinity to exceed oceanic values (Samarasinghe and Lennon 1987). The macrotidal phenomenon may be exposing the oysters to constant osmotic stress, stimulating spawning throughout the year.

Salinity influences various physiological mechanisms in Crassostrea, such as clearance rates and oxygen consumption (Casas et al. 2018), cytogenetic processes (Qin et al. 2018), and the reproductive cycle (George-Zamora et al. 2003; Paixão et al. 2013). In the months of more significant rainfall in the Paciência estuary (February to July), a decrease in salinity was observed and an increase in the frequency of recovering oysters (IIIC stage). Due to heavy rainfall, the reduction in salinity may have stimulated gamete release, since oocytes submitted to conditions outside the tolerance limits of the species can undergo cytolysis and removal from the follicles (Lenz and Boehs 2011). However, a second spawning peak was observed in the low rainfall period (October to December), suggesting that increases or decreases in salinity may stimulate spawning. Nascimento and Lunetta (1978) reported that gamete release in oysters is not concomitant for all individuals and the emptying of the gonad is a slow process where some individuals have partial emptying throughout the year.

Food quality and availability exert a strong influence on the accumulation of nutritional reserves for later release of gametes (Chávez-Villalba et al. 2000). For example, phytoplankton blooms may induce spawning (Dridi et al. 2014; Antonio and Camacho 2019). Chlorophyll $a$ and particulate organic matter (POM) were significantly higher in the rainy season in our study area, indicating higher primary productivity. A large number of individuals in stage IIIC at this time indicates intense spawning, with release, production and maturation of new gamete cohorts over a short period, taking advantage of greater food availability. 
Females predominated, but not significantly, in the Paciência estuary, agreeing with other studies on Crassostrea rhizophorae (Nascimento and Lunetta 1978; Christo and Absher 2006; Lenz and Boehs 2011) and Crassostrea brasiliana (= C. gasar) (Castilho-Westphal et al. 2015). The proportion of hermaphrodites was low (2.6\%) in the Paciência estuary, similar to what was observed in other Crassostrea species (Paixão et al. 2013; Lenz and Boehs 2011; Nascimento and Lunetta 1978).

The condition index is typically used to evaluate meat quality and bivalve mollusk-culture productivity (Rebelo et al. 2005). The condition index is conditioned by environmental variables (Prieto et al. 1999; Nishida et al. 2006), and high CI values may indicate full or partially filled gonads, while low values may be associated with gonad emptying and reabsorption (Nascimento and Pereira 1980). The condition index in our study presented higher values in the rainy months, between March and May, similarly to Lenz and Boehs (2011), who recorded higher CI values during rainy months, relating to greater food availability. Higher meat yield is related to individuals in gametogenesis and mature stages, as in these phases, reserve accumulation peaks, and follicles and acini are fully developed (Galvão et al. 2000). However, in our study, CI peaked in May, corresponding to a period of low maturation (IIIA) with high spawning (IIIB) and recovery (IIIC), reinforcing the idea that the mangrove oyster has a continuous process of gamete production and release yearround in tropical areas (Lenz and Boehs 2011).

\section{CONCLUSIONS}

Mangrove oysters, Crassostrea rhizophorae cultured in the macrotidal estuary of the Paciência River showed continuous reproduction throughout the year, making it possible to obtain oyster seeds year-round, with has the potential to enable the expansion of small oyster farms in the region. Gonadal development was influenced by the seasonal variation of rainfall, but the low variation in temperature seems to be the main determinant factor of the year-round reproduction, while salinity and food availability trigger the main spawning events. As an indicator of animal welfare and reserve-storage evaluation, the condition index did not correspond with the reproductive state of the oysters to correspond with maturation and gametogenesis. Assessment of oyster reproduction and recruitment is needed along the estuarine salinity gradient to determine the optimal location for seed collection and on-growing.

\section{ACKNOWLEDGMENTS}

This work was supported by Fundação de Amparo à Pesquisa e ao Desenvolvimento Científico e Tecnológico do Maranhão - FAPEMA (project Universal-00767/13). The authors thank the staff of the Laboratory of Physioecology,
Reproduction and Cultivation of Marine organisms at Universidade Estadual do Maranháo for assistance with the histological analysis.

\section{REFERENCES}

Antonio, I.G.; Camacho, A.P. 2019. Reproduction of the introduced oyster Crassostrea gigas (Bivalvia: Ostreidae) cultured on rafts in Spain. Acta Zoologica, 100: 257-267.

Bacon, P.R. 1971. Studies on the biology and cultivation of the mangrove oyster in Trinidad with notes on the other shellfish resource. Tropical Science, 12: 265-278.

Casas, S.M.; Lavaud, R.; La Peyre, M.K.; Comeau, L.A.; Filgueira, R.; La Peyre, J.F. 2018. Quantifying salinity and season effects on eastern oyster clearance and oxygen consumption rates. Marine Biology, 165: 90. doi.org/10.1007/s00227-018-3351-x

Castilho-Westphal, G.G.; Magnani, F.P.; Ostrensky, A. 2015. Gonad morphology and reproductive cycle of the mangrove oyster Crassostrea brasiliana (Lamarck, 1819) in the baía de Guaratuba, Paraná, Brazil. Acta Zoologica, 96: 99-107.

Chávez-Villalba, J.; Mingant, C.; Cochard, J.C.; Pennec, M. Le. 2000. Gamétogenèse chez l'huître Crassostrea gigas de l'Aber Benoît (Bretagne, France), à la limite nord de son aire de reproduction. Haliotis, 30: 1-12.

Christo, S.W.; Absher, T.M. 2006. Reproductive period of Crassostrea rhizophorae (Guilding, 1828) and Crassostrea brasiliana (Lamark, 1819) (Bivalvia: Ostreidae) in Guaratuba Bay, Paraná, Brazil. Journal of Coastal Research, 39: 1215-1218.

Costa, V.B. da.; Sousa, E.B. de.; Pinheiro, S.C.C.; Pereira, L.C.C.; Costa, R.M. da. 2011. Effects of a high energy coastal environment on the structure and dynamics of phytoplankton communities (Brazilian Amazon littoral). Journal of Coastal Research, 64: 354-358.

Cubillo, A.M.; Peteiro, L.G.; Fernández-Reiriz, M.J.; Labarta, U. 2012. Influence of stocking density on growth of mussels (Mytilus galloprovincialis) in suspended culture. Aquaculture, 342-343: 103-111.

Dridi, S.; Romdhane, M.S.; Elcafsi, M. 2014. Gametogenic cycle of Crassostrea gigas in contrasting Mediterranean habitats: marine (Gulf of Tunis) and continental (Bizert lagoon) culture sites. Journal of Biological Research-Thessaloniki, 21: 13. doi:10.1186/2241-5793-21-13

Funo, I.C. da S.A.; Antonio, I.G.; Marinho, Y.F.; Monteles, J.S.; Lopes, R.G.P.S.; Gálvez, A.O. 2019. Recruitment of oyster in artificial collectors on the Amazon macrotidal mangrove coast. Ciência Rural, 49: e20180482.

Galvão, M.S.N.; Pereira, O.M.; Machado, I.C.; Henrique, M.B. 2000. Aspectos reprodutivos da ostra Crassostrea brasiliana de manguezais do estuário de Cananéia, SP $\left(25^{\circ} \mathrm{S}-48^{\circ} \mathrm{W}\right)$. Boletim do Instituto de Pesca, 26: 147-162.

George-Zamora, A.; Sevilla-Hernandez, M.L.; Aldana-Aranda, D. 2003. Ciclo gonadico del ostión americano Crassostrea virginica (Lamellibranchia: Ostreidae) en Mecoacán, Tabasco, Mexico. Revista de Biología Tropical, 51(supl. 4): 109-117. 
Gomes, C.H.A.M.; Silva, F.C.; Lopes, G.R.; Melo, C.M.R. 2014. Ciclo reprodutivo da ostra Crassostrea gasar. Brazilian Journal of Biology, 74: 967-976.

Guimarães, I.M.; Antonio, I.G.; Peixoto, S.; Olivera, A. 2008. Influência da salinidade sobre a sobrevivência da ostra-domangue, Crassostrea rhizophorae. Arquivos de Ciências do Mar, 41: $118-122$.

Jeffrey, S.W.; Humphrey, G.F. 1975. New spectrophotometric equations for determining chlorophylls a, b, c1 and c2 in higher plants, algae and natural phytoplankton. Biochemie und Physiologie der Pflanzen, 167: 191-194.

Lenz, T.; Boehs, G. 2011. Ciclo reproductivo del ostión de manglar Crassostrea rhizophorae (Bivalvia: Ostreidae) en la Bahía de Camamu, Bahia, Brasil. Revista de Biologia Tropical, 59: 137-149.

Lopes, R.G.P.S.; Antonio, Í.G.; Tchaika, L.; Barros, M.C.; Fraga, E. 2018. Molecular identification of native oysters on the coast of Maranhão, Brazil. Boletim do Instituto de Pesca, 44: e377.

Nascimento, I. A.; Lunetta, J.E. 1978. Ciclo sexual da ostra de mangue e sua importância para o cultivo. Boletim de Fisiologia Animal da Universidade de São Paulo, 2: 63-93.

Nascimento, I.A.; Pereira, S.A. 1980. Changes in the condition index for mangrove oysters (Crassostrea rhizophorae) from Todos os Santos Bay, Salvador, Brazil. Aquaculture, 20: 9-15.

Nascimento Jr, W.R.; Souza-Filho, P.W.; Proisy, C.; Lucas, R.M.; Rosenqvist, A. 2013. Mapping changes in the largest continuous Amazonian mangrove belt using object-based classification of multisensor satellite imagery. Estuarine, Coastal and ShelfScience, 117: 83-93.

Nishida, A.K.; Nordi, N.; Alves, R.R.N. 2006. Molluscs production associated to lunar-tide cycle: A case study in Paraíba State under ethnoecology viewpoint. Journal of Ethnobiology and Ethnomedicine, 2: 28. doi.org/10.1186/1746-4269-2-28

Paixão, L.; Ferreira, M.A.; Nunes, Z.; Fonseca-Sizo, F.; Rocha, R. 2013. Effects of salinity and rainfall on the reproductive biology of the mangrove oyster (Crassostrea gasar): Implications for the collection of broodstock oysters. Aquaculture, 380-383: 6-12.

Pantoja, J.C.D.; Oliveira, L.F.S.; Ferreira, M.A.P.; Silva, B.R.M.; Nunes, Z.M.P.; Mendes, Y.A.; Oliveira, R.S.; Rocha, R.M. 2020. Salinity and rainfall as inducers of cell proliferation and apoptosis in mangrove oyster Crassostrea gasar spermatogenesis. Regional Studies in Marine Science 39: 101411.

Prieto, A.S.; Vasquez, M.; Ruiz, L.J. 1999. Dinámica energética del crecimiento en una población del mejillón Perna perna
(Filibranchia: Mytilidae) en el noreste del Estado Sucre, Venezuela. Revista de Biología Tropical, 47: 399-410.

Qin, Y.; Xiao, S.; Ma, H.; Mo, R.; Zhou, Z.; Wu, X.; et al. 2018. Effects of salinity and temperature on the timing of germinal vesicle breakdown and polar body release in diploid and triploid Hong Kong oysters, Crassostrea hongkongensis, in relation to tetraploid induction. Aquaculture Research, 49: 3647-3657.

Rebelo, M.F.; Amaral, M.C.R.; Pfeiffer, W.C. 2005. Oyster condition index in Crassostrea rhizophorae (Guilding, 1828) from a heavymetal polluted coastal lagoon. Brazilian Journal of Biology, 65: $345-351$.

Rios, E.C. 2009. Compendium of Brazilian Sea Shells. Evangraf, Rio Grande, 668p.

Rodríguez-Jaramillo, C.; Hurtado, M.A.; Romero-Vivas, E.; Ramírez, J.L.; Manzano, M.; Palacios, E. 2008. Gonadal development and Histochemistry of the Tropical oyster, Crassostrea corteziensis (Hertlein, 1951) during an Annual reproductive cycle. Journal of Shellfish Research, 27: 1129-1141.

Samarasinghe, J.R.S.; Lennon, G.W. 1987. Hypersalinity, flushing and transient salt-wedges in a tidal gulf - an inverse estuary. Estuarine, Coastal and Shelf Science 24: 483-498.

Sampaio, D.S.; Santos, M.L.S.; Tagliaro, C.H.; Beasley, C.R. 2020. Variation in environmental characteristics of waters among Amazon coast oyster culture units. Acta Amazonica, 50: 295-304.

Schettini, C.A.F.; Asp, N.E.; Ogston, A.S.; Gomes, V.J.C.; McLachlan, R.L.; Fernandes, M.E.B.; Nittrourer, C.A.; Truccolo, E.C.; Gardunho, D.C.L. 2020. Circulation and fine-sediment dynamics in the Amazon Macrotidal Mangrove Coast. Earth Surface Processes and Landforms, 45: 574-589.

Silva, O.L.L.; Macedo, A.R.G.; Nunes, E.S.C.L.; Campos, K.D.; Araújo, L.C.C.; Tiburço, X.; et al. 2020. Effect of environmental factors on the fatty acid profiles and physicochemical composition of oyster (Crassostrea gasar) in Amazon estuarine farming. Aquaculture Research 51: 2336-2348.

Souza Filho, P.W.M. 2005. Costa de manguezais de macromaré da Amazônia: cenários morfológicos, mapeamento e quantificação de áreas usando dados de sensores remotos. Revista Brasileira de Geofisica, 23: 427-435.

Vélez, A.R. 1977. Annual reproductive cycle of the oyster Crassostrea rhizophorae (Guilding) from Bahía de Mochima. Boletin del Instituto Oceanografico Universidad de Oriente, 16: 87-98.

\author{
RECEIVED: $12 / 08 / 2020$ \\ ACCEPTED: 09/03/2021 \\ ASSOCIATE EDITOR: Bruno Spacek Godoy
}


SUPPLEMENTARY MATERIAL (only available in the electronic version)

Antonio et al. Reproductive cycle of the mangrove oyster, Crassostrea rhizophorae (Bivalvia: Ostreidae) cultured in a macrotidal high-salinity zone on the Amazon mangrove coast of Brazil

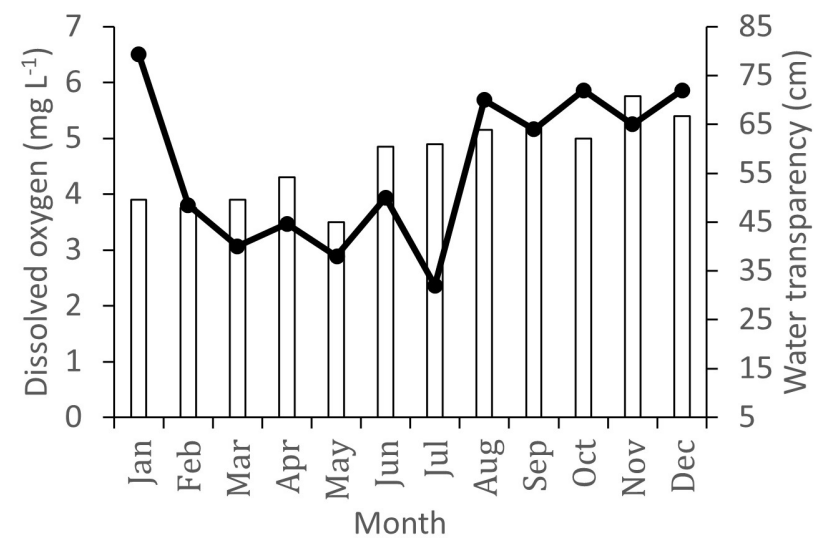

Dissolved oxygen

Water transparency

Figure S1. Mean monthly values of dissolved oxygen and water transparency at the culture area of mangrove oysters, Crassostrea rhizophorae in the estuary of the Paciência River, Maranhão, Brazil, in 2013.

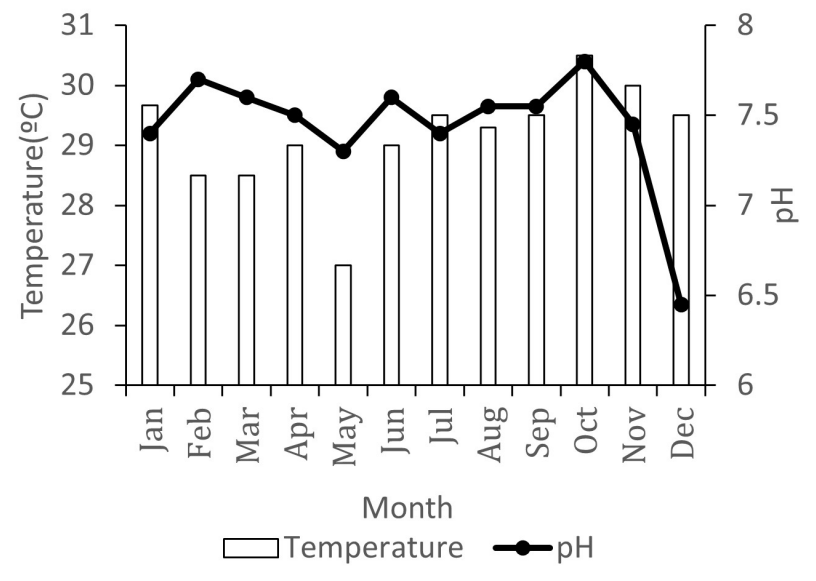

Figure S2. Mean monthly values of temperature and $\mathrm{pH}$ at the culture area of mangrove oysters, Crassostrea rhizophorae in the estuary of the Paciência River, Maranhão, Brazil, in 2013. 